Hugoye: Journal of Syriac Studies, Vol. 17.2, 191-193

(C) 2014 by Beth Mardutho: The Syriac Institute and Gorgias Press

\title{
INTRODUCTION
}

\section{NOTE ON THE TERM "GARSHUNOGRAPHY"}

\author{
George A. KiraZ \\ Beth Mardutho, Piscataway, NJ
}

The current issue of Hugoye contains papers from a conference titled Garshunography in the Syriac Tradition. This brief note summarizes the argument, published elsewhere, ${ }^{1}$ for coining the term garshunography.

The term Garshuni, whose origin is unknown, is mostly used to describe Arabic texts written in the Syriac alphabet. It has also been expanded to apply to other languages that are written in the Syriac alphabet. The phenomenon itself, viz. using the script of one language to write utterances of another language which already has a script associated with it socioliguistically, does not have linguistic technical term.

Two technical terms have already been used for this phenomenon. Recently, a book was published on the topic and using the term allography. ${ }^{2}$ Note that the prefix allo- denotes variation or departure from the norm which indeed seems applicable here. Allography, however, means something totally different in writing

${ }^{1}$ George A. Kiraz, 'Garshunography: Terminology and Some Formal Properties of Writing One Language in the Script of Another' in J. den Heijer, A. Schmidt, and T. Pataridze (eds.), Scripts beyond Borders. A Survey of Allographic Traditions in the Euro-Mediterranean World (Louvain: Peeters, 2014) 65-74.

${ }^{2}$ See note 1 . 
systems: ${ }^{3}$ a) to describe a diachronic graphical variant of writing such as the interchangeable use of $\langle\mathrm{u}\rangle$ and $\left.<_{\mathrm{v}}\right\rangle$ in the Latin script, or the writing of Dutch $\langle\ddot{y}\rangle$ for $\langle i j\rangle$; b) to designate realized variants of a grapheme such as Greek $\langle\sigma\rangle$ and $\langle\varsigma\rangle$ or Syriac $<_{\boldsymbol{D}}>$ and $<_{\boldsymbol{\Psi}}>$; c) to denote instances of one grapheme in different fonts such as $<\mathrm{a}$ a $\boldsymbol{a}>$ (Arial, Garamond, Lucidia); ${ }^{4} \mathrm{~d}$ ) with the term allograph recognition 5 to describe the recognition of variations of the same grapheme from different hands. All of the above usages have something in common: an allograph describes a variation of a grapheme (the same way an allophone is an instance of a phoneme and an allomorph is an instance of a morpheme). Earlier, the term heterography was used for this purpose. ${ }^{6}$ Here too, the term has a different meaning in the field of writing systems: "a differentiation in spelling which distinguishes different meanings of homophonous words or phrase"7 such as English right, rite, write, and wright. Both allography and heterography, while applicable, have already attained different technical meanings in writing systems for quite some time. The same can be said for the term transliteration. Using any of them for something that is quite different from their original meaning would overlead them and cause ambiguity in the technical terminology of writing systems.

I advocated in the paper mentioned earlier that the existing term Garšunini be used as a source to coin a term for the phenomenon itself; hence, garšnnography (or simply garshunography). To those who might object that the term sounds 'foreign' as it has no Latin-Greek root, I pointed out other linguistic terms that are now ubiquitous: schwa from the Semitic grammatical tradition, sandhi from Sanskrit, abjad from the Arabic mnemonic for 'alphabet', kashida from Persian, and tatwill from Arabic to name a

${ }^{3}$ F. Coulmas, The Blackwell Encyclopedia of Writing Systems (1999) 9.

${ }^{4}$ G. Sampson, Writing Systems (1985) 25.

${ }^{5}$ H. Teulings, L. Schomaker, J. Gerritsen, H. Drexler and M. Alberts, 'An on-line handwriting-recognition system based on unreliable modules', in R. Plamondon and C. G. Leedham, Computer Processing of Handwriting (1990) 167-85.

${ }^{6}$ A. Mengozzi, ‘The History of Garshuni as a Writing System’ 297; A. Mengozzi, 'Garshuni', in S. Brock, A. Butts, G. Kiraz, and L. Van Rompay, Gorgias Encyclopedic Dictionary of the Syriac Heritage (2011) 172.

${ }^{7}$ Coulmas 202. 
few. To those who may object that Garšūnī is an ethnolexeme, I pointed out that the utterance /garšunin/ is used in many languages such as Arabic, Turkish, Malayalam, and all sorts of European languages within the Syriac diaspora. The term already appears in the Oxford English Dictionary with a citation from as early as $1856^{8}$ and in Webster's Third. ${ }^{9}$ The fact that the etymology, origin, and basic meaning of the word is unknown remove any possibility of ambiguity.

I then used the term garšnnography productively and defined the following terms:

garšñnographeme (adj. garšnunographemic) An adaptation of a grapheme from the target script to represent a grapheme or phoneme from the source language; e.g., $<\boldsymbol{\rangle}>$ from Syriac $<\boldsymbol{y}^{>}$ for Arabic $<_{ج}>$.

allogaršnnographs Allographs of a garšunographeme.

allogaršnnography (adj. allogaršunographic) The realization of variants of a garšunnographic text; e.g., Syriac text written in both the Arabic and Latin scripts.

hetero-garšünographeme (adj. hetero-garšünographemic) A borrowing of a grapheme from the script of the source language to be used in the target script; e.g., Malayalam graphemes used in Syro-Malayalam garšūnography.

When using the term Garšunīi unmodified, one understands that the source language is Arabic and the target script is Syriac. As the term garshunography here knowns no source or target language (it describes a writing phenomenon), the existing tradition of compounding the target script with the source language can be used. Hence, one can speak of Judeo-Arabic garshunography, Armeno-Turkish, garshunography, etc. For details on the argument, see the reference in footnote 1.

${ }^{8}$ J. Simpson and E. Weiner (eds.), Oxford English Dictionary, $2^{\text {nd }}$ ed., 20 vols. (2009).

9 'karshuni.' Webster's Third New International Dictionary, Unabridged (2002). http:// unabridged.merriam-webster.com (25 Oct. 2011). 
